\title{
DEVELOPMENT OF A CREATIVE MANUAL BOOK FOR SCIENCE YOUTH SCIENTIFIC GROUP
}

\author{
Ismail Fikri Natadiwijaya*, Lissa, Lesy Luzyawati \\ Program Studi Pendidikan Biologi, Fakultas Keguruan dan Ilmu Pendidikan, Universitas \\ Wiralodra, Jl.Ir.H.Juanda, Km.3,Indramayu \\ *fikrinatadiwijaya86@gmail.com
}

Doi: 10.31943/mangiferaedu.v5i2.117

Received: November 25, 2020 Accepted: January 15, $2021 \quad$ Published: January 31, 2021

Citation: Natadiwijaya, I. F., Lissa, \& Luzyawati, L. (2021). Development of A Creative

Manual Book for Science Youth Scientific Group. Jurnal Mangifera Edu, 5(2), 150-159.

\begin{abstract}
One of the world of education components that specifically aims to develop students' creativity is the Youth Scientific group (KIR). Based on the case studies, information was obtained that KIR participants generally still have difficulty generating ideas. Some of the factors that caused KIR participants' difficulty in creating ideas were lack of knowledge and the absence of a guide to guide them in making ideas. The purpose of this study was to develop a technical guidebook for making ideas for KIR students. Products are developed through development research in a sequence of steps: Define, design, and develop. This study provides the results that the product being developed has the following characteristics: 1) consists of 2 parts, namely the formation of new cognitive schemes and the formation of product idea designs, 2) The section on the formation of the New Cognitive Schema is designed based on the cognitive load theory, 3)The product idea design section is designed based on the Creative Process Learning theory. The product developed has a score with a very decent category but needs to be given significant improvements in the aspect of indicators and the addition of entrepreneurship material and SWOT analysis.
\end{abstract}

Keywords: Creative Manual Book, Generating Idea, Science Youth Scientific

\section{ABSTRAK}

Salah satu komponen dalam dunia pendidikan yang secara khusus bertujuan untuk mengembangkan kreativitas peserta didik adalah kelompok Ilmiah Remaja (KIR). Berdasarkan studi kasus, diperoleh informasi bahwa peserta KIR umumnya masih kesulitan dalam menciptakan ide (generate idea).Penyebab sulitnya peserta KIR dalam menciptakan ide adalah kurangnya pengetahuan serta tidak adanya suatu petunjuk yang menuntun mereka dalam membuat ide. Tujuan penelitian ini adalah mengembangkan sebuah buku petunjuk teknis pembuatan ide bagi siswa KIR. Produk dikembangkan melalui penelitian pengembangan dengan urutan langkah : Define, design, dan develop. Penelitian ini memberikan hasil bahwa produk yang dikembangkan memiliki karakteristik: 1)terdiri dari 2 bagian, yaitu bagian pembentukan skema kognitif baru, dan bagian pembentukan rancangan ide produk, 2) Bagian pembentukan Skema Kognitif Baru diranvang berdasarkan teori Cognitive load theory, dan 3)Bagian pembentukan rancangan ide produk dirancang berdasarkan teori Creative Process Learning. Produk yang dikembangkan 
Jurnal Mangifera Edu, Volume 5, Issue 2, January 2021, 150-159

memiliki skor dengan kategori sangat layak tetapi perlu diberi perbaikan yang signifikan pada aspek indicator serta penambahan materi enterpreneurship dan analisis SWOT.

Kata Kunci: Creative Manual Book, Kelompok Ilmiah Remaja, Penciptaan ide

\section{PENDAHULUAN}

Tujuan pendidikan pada saat ini telah mengarah pada dihasilkannya lulusan yang kreatif. Lulusan yang mampu merespon secara kreatif terhadap lingkungan dan permasalahannya, akan lebih mampu menghadapi tantangan abad ke-21, karena akan memberikan kontribusi positif terhadap dunia personal, sosial, teknologi dan ekonomi yang akan mereka diami sebagai orang dewasa (Trnova, 2014; Diawati, 2017).

Salah satu komponen dalam dunia pendidikan yang secara khusus bertujuan untuk mengembangkan kreativitas peserta didik adalah kelompok Ilmiah Remaja (KIR) (Septiriani \& Hasanah, 2017). Secara umum tujuan KIR adalah untuk meningkatkan kemampuan intelektual siswa yang tercermin dalam sikap dan tindakannya yang berdasarkan pada proses berpikir ilmiah dan kreatif serta mampu berperan aktif dalam pembangunan nasional (Aprianto et al., 2015).

Berdasarkan observasi yang telah dilakukan terhadap Kelompok Ilmiah Remaja (KIR) di salah satu SMA Negeri di Jawa Barat, diperoleh informasi bahwa peserta KIR umumnya masih kesulitan dalam menciptakan ide kreatif (generate idea). Peserta KIR umumnya menghasilkan ide produk yang "sudah ada", tanpa memikirkan kebaruan atau kebermanfaatan produk tersebut.

Berbagai penelitian mengungkap berbagai upaya membangun kreativitas peserta KIR, seperti melalui penggunaan artikel ilmiah (Listyaningsih et al., 2014), pemberian motivator dan pembimbing bidang karya ilmiah (Ardilawati, 2017), melalui pengoptimalan perpustakaan sekolah (Santoso \& Sos, 2015), serta melalui pembangunan motivasi dan efikasi diri (Pawitri \& Widiasavitri, 2019).

Penelitian-penelitian tersebut memberi informasi mengenai bagaimana membangun kreativitas peserta KIR pada tempatnya masing-masing, akan tetapi solusi tersebut masih belum mengarah pada bagaimana teknis membangun kreativitas melalui instruksi didaktik, sehingga bisa diterapkan pada tempat dan waktu yang berbeda. Oleh karena itu perlu dikembangkan suatu produk instruksi didaktik yang secara khusus berfungsi untuk membangun kreativitas peserta didik, khususnya peserta KIR.

Penelitian mengungkap bahwa kreativitas sangat berkaitan erat dengan pengetahuan (faktor internal), serta dipengaruhi oleh faktor eksternal seperti lingkungan serta ada atau 
tidaknya bahan ajar, media dan lain-lain (Beetlestone, 2011; Rigolizzo \& Amabile, 2015). Selain itu kreativitas dalam membuat ide dapat dilatih melalui teknik instruksional yang tepat (Natadiwijaya, et al., 2018). Teknik instruksional tersebut dikembangkan dengan mengintegrasikan antara creative process theory dengan cognitive load theory, dan terbukti telah berhasil meningkatkan keterampilan berpikir kreatif mahasiswa jurusan biologi (Natadiwijaya, et al., 2019).

Berdasarkan hal tersebut, perlu dikembangkan sebuah instruksional didaktik berupa buku petunjuk teknis pembuatan ide yang dimodifikasi dari temuan hasil penelitian di atas, yang selanjutnya dapat digunakan oleh siswa di lapangan. Oleh karena itu pada penelitian ini akan dikembangkan sebuah buku petunjuk teknis (manual book) yang berisi perintah instruksional untuk memandu peserta KIR dalam menciptakan dan mengembangkan ide penelitian di bidang sains.

\section{METODOLOGI PENELITIAN}

Jenis penelitian yang digunakan pada penelitian ini adalah metode penelitian dan pengembangan (Research and Develoment (R\&D)). Model yang digunakan adalah penelitian pengembangan model 4D. Model pengembangan 4D terdiri atas 4 tahap utama yaitu: Define (Pendefinisian), Design (Perancangan), Development (Pengembangan) dan Disseminate (Penyebaran) (Thiagarajan, 1974). Metode dan model ini dipilih karena bertujuan untuk menghasilkan produk berupa Creative Manual Book bagi peserta KIR bidang sains.

Pada penelitian ini hasil tahap define merupakan masalah yang melatarbelakangi penelitian, sedangkan kegiatan pengembangan produk dilakukan hanya sampai tahap Development (pengembangan). Oleh karena itu metode pada penelitian ini mencakup tahap design dan develop yang secara rinci ditunjukkan Tabel 1.

Tabel 1. Metode Penelitian Tiap Tahap Pengembangan

\begin{tabular}{|c|c|c|c|c|}
\hline Tahap & Instrumen & Data & $\begin{array}{l}\text { Metode Analisis } \\
\text { Data }\end{array}$ & Hasil \\
\hline Design & - & $\begin{array}{l}\text { Draf Creative } \\
\text { manual Book }\end{array}$ & Coding data & $\begin{array}{l}\text { Karakteristik } \\
\text { Produk }\end{array}$ \\
\hline Development & $\begin{array}{l}\text { Instrumen } \\
\text { validasi }\end{array}$ & $\begin{array}{lr}\begin{array}{l}\text { Komentar } \\
\text { saran }\end{array} & \text { dan } \\
\text { validator } & \\
\text { Skor } & \text { yang } \\
\text { diberikan } & \\
\text { validator } & \end{array}$ & $\begin{array}{l}\text { - Perhitungan } \\
\text { skor } \\
\text { - Pengkriteriaan } \\
\text { skor }\end{array}$ & $\begin{array}{l}\text { Komentar dan saran } \\
\text { relevan } \\
\text { - Skor } \\
\text { - Kriteria skor }\end{array}$ \\
\hline
\end{tabular}


Jurnal Mangifera Edu, Volume 5, Issue 2, January 2021, 150-159

Pada tahap Design, data adalah berupa draf Creative Manual Book. Draf kemudian dianalisis melalui pengodean untuk dirumuskan secara jelas karakteristik produk yang dihasilkan. Produk draf Creative Manual Book selanjutnya diserahkan kepada validator pada tahap Development.

Teknik pengumpulan data pada tahap development adalah menggunakan instrumen lembar validasi. Data yang dihasilkan adalah berupa data kualitatif dan kuantitatif. Data kualitatif merupakan data yang berupa komentar dan saran terhadap manual book dari validator ahli, sedangkan data kuantitatif merupakan skor penilaian terhadap manual book dari validator ahli. Pedoman untuk perhitungan skor pada data kuantitatif ditunjukkan Rumus 1 (Sudijono,2011).

$$
\mathrm{P}=\frac{\sum_{i}^{n} x i}{n . k} \cdot 100
$$

Keterangan:

$$
\begin{array}{ll}
\sum_{i}^{\mathrm{p}} x i & : \text { Persentase penilaian } \\
\mathrm{N} & : \text { Jumlah poin penilaian dari subjek uji coba } \\
\mathrm{K} & : \text { Banyaknya subjek uji coba } \\
& \text { Skor penilaian tertinggi }
\end{array}
$$

Pedoman kriteria validitas berdasarkan skor yang diperoleh ditunjukkan tabel 2 (Sudijono, 2011).

Tabel 2. Pedoman Kriteria Validitas Produk

\begin{tabular}{ccc}
\hline Persentase & Kriteria Validitas & Keterangan \\
\hline $85-100$ & Sangat valid & Tidak perlu revisi \\
$70-84$ & Valid & Tidak perlu revisi \\
$55-60$ & Cukup Valid & Tidak perlu revisi \\
$50-54$ & Kurang valid & Perlu revisi \\
$0-49$ & Tidak valid & Revisi total \\
\hline
\end{tabular}

Perhitungan skor dengan hasil kurang dari 55\% bermakna bahwa produk perlu direvisi, sedangkan perhitungan skor dengan hasil lebih dari 55\% bermakna bahwa maka produk tidak perlu direvisi, hanya disarankan melakukan perbaikan komentar dan saran yang diberikan oleh validator.

\section{HASIL DAN PEMBAHASAN}

Hasil tahap design pada penelitian pengembangan Creative Manual Book ini adalah berupa produk tiga dimensi (3D) berbentuk buku, yang selanjutnya produk tersebut divalidasi oleh ahli pada tahap penelitian Development. Adapun hasil dari tahap design menghasilkan Creative Manual Book dengan karakteristik sebagai berikut. 
a. Terdiri dari 2 bagian, yaitu bagian pembentukan skema kognitif baru, dan bagian pembentukan rancangan ide produk. Creative Manual Book terdiri dari 2 bagian yang tersusun saling terkait, dimana hasil dari begian pertama menjadi bahan untuk diolah pada bagian berikutnya. Creative Manual Book dirancang dengan menggunakan strategi yang dapat membentuk aktivitas belajar yang menunjang terhadap pembentukan keterampilan berpikir kreatif. Adapun ringkasan dari karakteristik kedua bagian tampak pada gambar 1 .

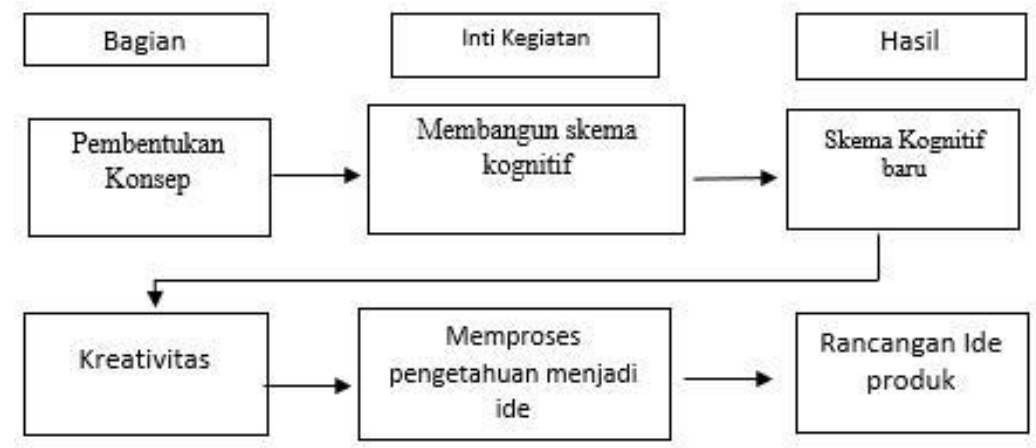

\section{Gambar 1. Ringkasan Karakteristik Creative Manual Book yang Berupa dua Fase Pembelajaran}

b. Pembentukan Skema Kognitif Baru diranvang berdasarkan teori Cognitive load theory. Bagian pertama dari Creative manual Book dirancang supaya terbentuk skema kognitif baru. Skema kognitif baru yang dimaksud adalah berupa keseluruhan struktur kognitif tentang macam-macam informasi konsep dan produk sains yang telah terproses (dipahami, diterapkan, dianalisis) dan disimpan dalam memori jangka panjang, supaya mudah dipanggil saat mahasiswa membuat ide. Skema kognitif dibentuk berdasarkan Cognitive load Theory yaitu berupa serangkaian langkah pembelajaran yang dirancang untuk mengurangi usaha mental mahasiswa dalam memproses informasi. Adapun ringkasan kegiatan pada bagian pertama dari Creative Manual Book tampak pada Gambar 2.

c. Pembentukan rancangan ide produk dirancang berdasarkan teori Creative Process Learning.. Creative Manual Book dirancang supaya terbentuk berbagai macam ide produk sains kreatif. Ide tersebut dapat terbentuk melalui serangkaian aktivitas belajar berdasarkan Creative Process Learning, yaitu persiapan, inkubasi, iluminasi dan verifikasi. Ide terbentuk secara bertahap, melalui suatu rangkaian "transformasi ide". Setiap langkah pada rangkaian transformasi ide memiliki peran bagi langkah berikutnya, sampai membentuk hasil akhir yang berupa "rancangan ide produk sains". Rancangan tersebut merupakan ide produk sains yang telah diuraikan secara rinci segala aspeknya 
supaya mudah diproses menjadi produk nyata. Adapun ringkasan dari karakteristik yang telah dibahas tampak pada Gambar 2.

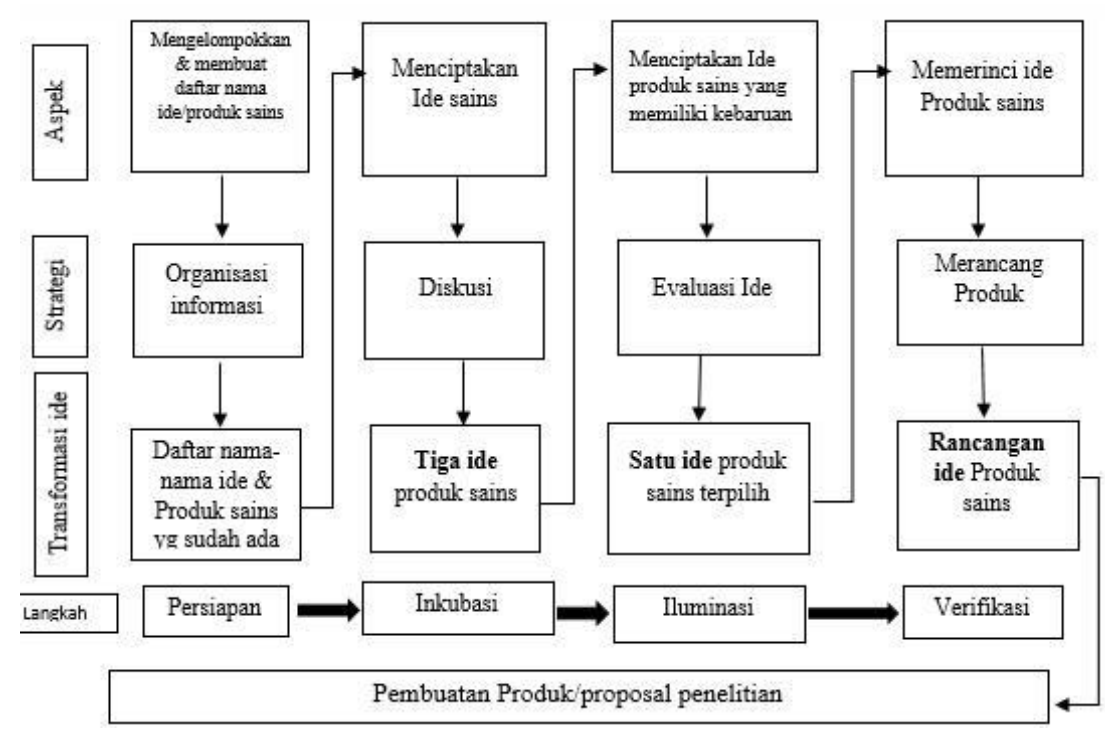

\section{Gambar 2. Ringkasan Proses Pembentukan Ide Produk Sains Kreatif yang Terjadi Pada Creative Manual Book}

Tahap Development bertujuan untuk memvalidasi Creative Manual Book yang telah dirancang. Creative Manual Book tersebut selanjutnya dinilai dan diberi masukan dari satu validator ahli dan satu validator praktisi (guru Biologi SMA). Dari proses validasi yang dilakukan oleh kedua validator maka diperoleh data kuantitatif berupa skor validitas dari produk Creative Manual Book ini dengan hasil sebagai berikut :

Tabel 2. Rekapitulasi Validasi Creative Manual Book dari Ahli

\begin{tabular}{lcccc}
\hline \multirow{2}{*}{ No } & Validator & \multicolumn{3}{c}{ Validitas } \\
\cline { 3 - 5 } & & $\begin{array}{c}\text { Jumlah } \\
\text { skor }\end{array}$ & $\begin{array}{c}\text { Rata-rata } \\
\text { skor }\end{array}$ & Kategori \\
\hline 1. & $\mathrm{X}$ & 81 & $92 \%$ & Sangat layak \\
2. & $\mathrm{Y}$ & 71 & $80,6 \%$ & Sangat layak \\
& Rerata & \multicolumn{3}{c}{$86,30 \%$} \\
& Kategori & \multicolumn{3}{c}{ Sangat layak } \\
\hline
\end{tabular}

Berdasarkan data tersebut diambil kesimpulan bahwa produk Creative manual Book yang telah dikembangkan tidak perlu direvisi, hanya disarankan melakukan perbaikan berdasarkan komentar dan saran yang diberikan oleh validator. Adapun komentar dan saran (data kualitatif) demi perbaikan produk Creative Manual Book untuk peserta KIR adalah sebagai berikut: 
1. Pada validasi pertama validator Bapak $X$ memberikan komentar dan saran perbaikan bahwa "Creative Manual Book” sudah baik, hanya banyak kesalahan pengetikan dan perlu ditambahkan materi sains untuk memenuhi indikator pembelajaran”. Selain itu, validator Bapak X juga memberikan masukan bahwa perlu diberi perbaikan yang signifikan pada aspek indikator serta penambahan materi Bioenterpreneurship dan analisis SWOT.

2. Validator Kedua Bapak Y memberi komentar dan saran "Muatan sains nya lebih di perdalam". Selain itu, validator bapak Y juga memberikan masukan bahwa penggunaan tata bahasa di perbaiki serta menambahkan daftar pustaka.

Tingginya validitas produk Creative Manual Book memberi arti bahwa produk tersebut sudah sangat baik apabila dinilai dari segi konstruk/isi. Adapun pembahasan terkait konstruk/isi dari karakteristik produk Creative manual Book yang dihasilkan adalah sebagai berikut.

Rangkaian aktivitas yang tertulis pada instruksional Creative Manual Book dimulai dengan bagian "pembentukan skema kognitif baru". Aktivitas diawali dengan tugas belajar mandiri melalui studi literatur tentang aplikasi sains dalam kehidupan sehari-hari (SALINGTEMAS). Tujuan dari belajar mandiri adalah untuk menghasilkan "pengetahuan awal". Perlunya pengetahuan awal ini sesuai dengan pernyataan Kalyuga (2009), bahwa apabila tidak cukup tersedia pengetahuan awal, maka pencarian informasi oleh memori kerja mungkin menjadi aktivitas yang acak dan tidak sistematis.

Aktivitas berikutnya adalah mengorganisasi informasi, dilakukan melalui penulisan nama produk membentuk seperangkat informasi yang disebut "daftar nama-nama produk sains". Dampak yang diharapkan dari rangkaian aktivitas tersebut adalah terbangunnya skema kognitif tentang aplikasi sains dalam kehidupan sehari-hari.

Aktivitas berikutnya adalah bagian "pembentukan rancangan ide produk”. Kegiatan dilakukan melalui diskusi ide secara kelompok, karena melalui aktivitas diskusi kelompok, peserta dapat mengembangkan pengetahuannya, serta mengurangi usaha mental dalam menyelesaikan permasalahan. Menurut temuan dari Omrod (2008), skema kognitif akan berkembang apabila setiap siswa bekerja sama berbagi pengalaman dengan siswa lain. Selain itu menurut Silver et al. (2007), siswa akan terbebani apabila harus menyelesaikan tugas yang kompleks secara individual, karena tidak dapat membagi pengetahuan dan tanggung jawab dengan temannya.

Kegiatan saling berbagi pengetahuan yang dilakukan melalui aktivitas diskusi akan membentuk "elemen mental". Elemen mental berupa kumpulan pengetahuan tentang 
produk-produk sains yang diperoleh setelah diskusi dilakukan. Selanjutnya elemen mental ini dikombinasikan sehingga membentuk "konfigurasi". Konfigurasi ini berbentuk ide-ide sains hasil pemikiran bersama (Gambar 3).

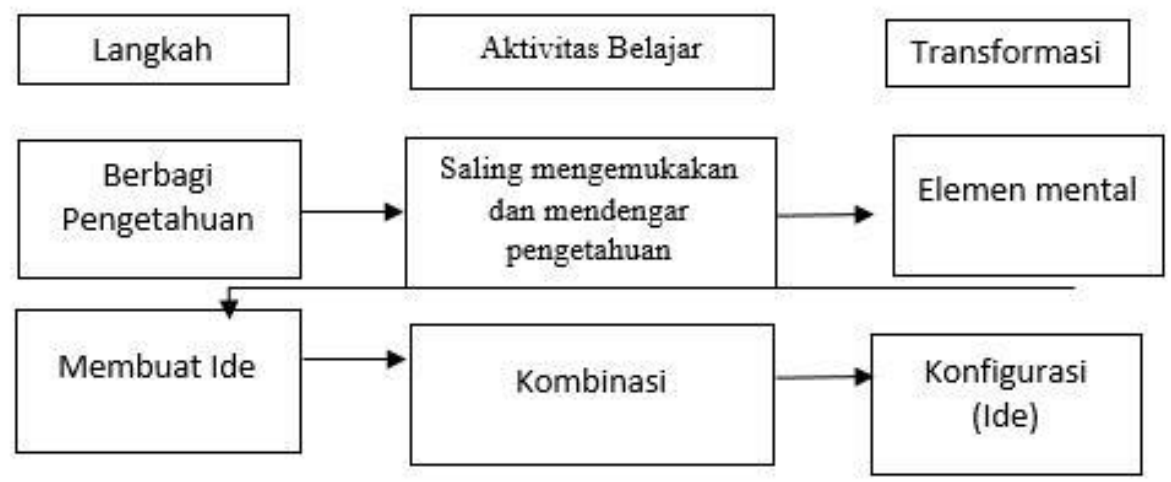

Gambar 3. Ringkasan Langkah diskusi, Aktivitas Belajar, dan Transformasi Informasi Yang Terjadi Pada Proses Pembentukan Ide

Pada penelitian ini, aktivitas diskusi ide dirancang untuk menghasilkan seperangkat informasi berupa tiga ide produk sains kreatif. Strategi diskusi ide merupakan strategi yang menunjang terhadap keterampilan berpikir kreatif. Menurut Al-Khatib (2012), strategi diskusi ide merupakan bentuk brainstorming yang dapat melatih berpikir kreatif. Selain itu, kegiatan diskusi juga dapat membuat mahasiswa terampil dalam mengkombinasikan pengetahuannya. Menurut Anderson, et al. (2014), inovasi dapat dimulai dari pemanfaatan atau pengkombinasian pengetahuan. Rangkaian aktivitas evaluasi ide dirancang supaya mahasiswa mampu membangun keaslian dalam berpikir. Hal tersebut senada dengan penemuan Rigollizo \& Amabile (2015), yang menyatakan bahwa evaluasi ide berfungsi sebagai cara untuk meningkatkan level kebaruan dan kebermanfaatan.

\section{SIMPULAN}

Berdasarkan hasil penelitian dan pembahasan dapat disimpulkan bahwa produk Creative manual Book memiliki karakteristik 1) Terdiri dari 2 bagian, yaitu bagian pembentukan skema kognitif baru, dan bagian pembentukan rancangan ide produk, 2) Bagian pembentukan Skema Kognitif Baru dirancang berdasarkan teori Cognitive load theory, 3) Bagian pembentukan rancangan ide produk dirancang berdasarkan teori Creative Process Learning. Produk yang dikembangkan memiliki skor dengan kategori sangat layak dan diberi perbaikan yang signifikan pada aspek indikator, diberi penambahan materi enterpreneurship dan analisis SWOT.

\section{UCAPAN TERIMAKASIH}


Jurnal Mangifera Edu, Volume 5, Issue 2, January 2021, 150-159

Terima kasih kami ucapkan kepada Universitas Wiralodra yang telah membiayai kegiatan penelitian ini. Terima kasih juga kami haturkan kepada para validator ahli instrumen penilaian produk yang telah menilai produk sehingga produk penelitian dapat dinilai.

\section{DAFTAR PUSTAKA}

Al-Khatib, B. (2012). The Effect of using Brainstorming Strategy in Developing Creative Problem Skills among Female Students in Princess Alia University College. American International Journal of Contemporary Research, 2(10).

Anderson, N., Potočnik, K., \& Zhou, J. (2014). Innovation and Creativity in Organizations: A State-of-the-Science Review, Prospective Commentary, and Guiding Framework. Journal of Management, 40(5), 1297-1333

Aprianto, W., Yanzi, H., \& Nurmalisa, Y. (2015). Pengaruh Kegiatan Organisasi Kesiswaan Kelompok Ilmiah Remaja (Kir) terhadap Pembentukan Sikap Ilmiah Siswa. Jurnal Kultur Demokrasi, 4(6).

Ardilawati, L. (2017). Upaya Pengembangan Kreativitas Peserta Didik melalui Kegiatan Ekstrakurikuler Karya Ilmiah di SMAN 21 Surabaya. Inspirasi Manajemen Pendidikan, 5(1).

Beetlestone, F. (2011)." Creative learning". Philadelphia: Open University Press.

Diawati, C. (2017). Modifikasi Alat Praktikum Kimia Instrumen Berbasis Proyek untuk Meningkatkan Keterampilan Berpikir Kreatif Mahasiswa Calon Guru. Universitas Pendidikan Indonesia.

Kalyuga, S. (2009). Knowledge Elaboration : A Cognitive Load Perspective, Elsevier,19,402-410.

Listyaningsih, R., Sudargo, F., \& Hidayat, T. (2014). Penggunaan Artikel Ilmiah Biologi untuk Menggali Kreativitas Rancangan Penelitian Peserta Kelompok Ilmiah Remaja. Mathematics and Sciences Forum 2014.

Natadiwijaya, I. F., Rahmat, A, Redjeki, S \& Anggraeni, S. (2018). Sikap Wirausaha mahasiswa Pada Perkuliahan Bioteknologi Bermuatan Bioentrepreneursship. Mangifera Edu, 3(1),

Natadiwijaya, I. F., Rahmat, A, Redjeki, S. \& Anggraeni, S. (2019). Preservices Creative Thinking skills On Biotechneur programs. Journal of Physics:Conf.Series.

Ormrod, J. E. (2008). Psikologi Pendidikan. Jakarta : Erlangga.

Pawitri, N. M. A., \& Widiasavitri, P. N. (2019). Peran Efikasi Diri dan Motivasi Berprestasi terhadap Kecenderungan Kreativitas dalam Menulis Karya Ilmiah pada Siswa SMA yang Menjadi Anggota Kelompok Ilmiah Remaja (KIR) di Denpasar. Jurnal Psikologi Udayana, 140-152.

Rigolizzo, M., \& Amabile, T. (2015). Entrepreneurial Creativity : The Role of Learning process and Work Environment Supports. Oxford : Oxford University Press 
Jurnal Mangifera Edu, Volume 5, Issue 2, January 2021, 150-159

Santoso, H., \& Sos, S. (2015). Kontribusi Perpustakaan Sekolah dalam Menunjang Kegiatan Kelompok Ilmiah Remaja (KIR).

Schnotz, W., \& Kürschner, C. (2007). A Reconsideration of Cognitive Load Theory. Journal of Educational Psychologist, 19. 469-508.

Septiriani, P., \& Hasanah, M. (2017). Korelasi Kegiatan Ekstrakurikuler Kelompok Ilmiah Remaja (KIR) dengan Kemampuan Literasi Informasi. BIBLIOTIKA: Jurnal Kajian Perpustakaan Dan Informasi, 1(2), 34-40.

Silver, C. E. H., Duncan, R. G., \& Chinn, C. A. (2007). Scaffolding and Achievement in Problem Based and Inquiry Learning. Educational Psychologist, 42(2), 99-107.

Sudijono, A. (2011). Pengantar Evaluasi Pendidikan. Jakarta: PT Rajagrafindo Persada.

Thiagarajan, S. (1974). Instructional Development for Training Teachers of Expectional Children. Minneapolis : Leadership Training Institute

Trnova, E. (2014). IBSE and Creativity Development. Science Education International, 25(1), 8-18. 